Discussion Paper No. 11-081

The Effect of Broadband Infrastructure on Entrepreneurial Activities:

The Case of Germany

Diana Heger, Miriam Rinawi, and Tobias Veith

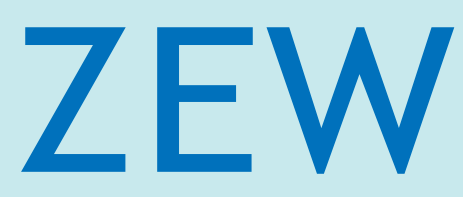

Zentrum für Europäische Wirtschaftsforschung $\mathrm{GmbH}$

Centre for European

Economic Research 
Discussion Paper No. 11-081

\title{
The Effect of Broadband Infrastructure on Entrepreneurial Activities: The Case of Germany
}

\author{
Diana Heger, Miriam Rinawi, and Tobias Veith
}

Download this ZEW Discussion Paper from our ftp server:

http://ftp.zew.de/pub/zew-docs/dp/dp11081.pdf

Die Discussion Papers dienen einer möglichst schnellen Verbreitung von neueren Forschungsarbeiten des ZEW. Die Beiträge liegen in alleiniger Verantwortung der Autoren und stellen nicht notwendigerweise die Meinung des ZEW dar.

Discussion Papers are intended to make results of ZEW research promptly available to other economists in order to encourage discussion and suggestions for revisions. The authors are solely responsible for the contents which do not necessarily represent the opinion of the ZEW. 


\section{Non-technical Summary}

In this paper we investigate whether local characteristics influence entrepreneurial activities. One local characteristic that may drive the decision to establish a firm in a specific region is the supply of infrastructure. Infrastructure important for entrepreneurial activity may take different forms and functions. First, trade and industrial growth require physical infrastructure like streets, rails and waterways. Second, particularly for knowledge- and technology-based ventures the knowledge infrastructure is crucial. Third, an additional type of knowledge spillovers may foster local entrepreneurial activities: the local business community. Those networks may help create specific and tacit business knowledge and contacts which may be vital for entrepreneurial firms. We further focus on a region's broadband availability which may spur entrepreneurial activities. New broadband infrastructure may reduce the necessity of physical proximity. Furthermore, taking broadband as a virtual marketplace and an infrastructure for customer contact, its roll-out and the increase of quality is a requirement for firm formations.

Using a county-year panel structure we consider the impact of broadband availability on company foundations and control for standard impact factors on venture activities. The central variable of our analysis is a broadband indicator. Broadband penetration is measured on a county basis. A county is equipped with broadband if at least one main distribution frame (MDF) in the county is upgraded to allow for broadband access. We account for different issues with MDFs: Multiple MDFs may be installed within one county, MDFs at county boundaries do not only provide access to households and companies in that county but also to connected consumers in the neighboring counties, and changes of county boundaries across time must be taken into account.

On sector level, we find a significantly positive influence of broadband availability on entrepreneurial intensities in high-tech industries like software and technology-intensive services (knowledge-intensive services). In contrast, no influence exists if we look at all sectors. Moreover, other infrastructural drivers of founding activities follow the results known from the literature. In consequence, our study provides evidence for an additional driver of entrepreneurial activities which supports the current broadband initiative in European countries and which also supports the effort to increase high-tech companies providing them with an adequate high-speed data infrastructure. 


\section{Nicht-technische Zusammenfassung}

In dieser Studie untersuchen wir, ob lokale Gegebenheiten das Gründungsgeschehen beeinflussen. Eine wesentliche regionale Eigenschaft, die die Entscheidung dort ein Unternehmen zu gründen beeinflussen kann, ist das Angebot an Infrastruktur. Die für die Gründungsentscheidung wichtige Infrastruktur kann verschiedene Formen und Funktionen annehmen. Erstens benötigen Handel und industrielle Entwicklung physische Infrastruktur wie Straßen, Schienen und Wasserwege. Zweitens ist vor allem für wissens- und technologieorientierte Gründungen die Wissensinfrastruktur wesentlich. Drittens kann eine weitere Form von Wissensspillovern die lokale Gründeraktivität begünstigen: die lokal ansässigen Unternehmen. Diese Netzwerke können beim Aufbau von spezifischem und implizitem Wissen und Kontakten helfen, die für neue Unternehmen überlebenswichtig sein können. Darüber hinaus betrachten wir die Breitbandverfügbarkeit in einer Region. Eine neue Brandbandinfrastruktur kann die Notwendigkeit der physischen Nähe reduzieren. Betrachtet man darüber hinaus Breitband als virtuellen Markt und als eine Infrastruktur für Kundenkontakt, dann sind der Ausbau und die Erhöhung der Qualität eine Voraussetzung für Unternehmensgründungen.

Wir nutzen eine Kreis-Jahr-Panelstruktur und kontrollieren für die Standardeinflussgroßen für Gründungstätigkeiten, um den Einfluss der Breitbandverfügbarkeit auf Unternehmensgründungen zu analysieren. Die zentrale Variable unserer Analyse ist ein Breitband-Indikator. Die Verbreitung von Breitband wird auf Kreisebene gemessen. Ein Kreis ist mit Breitband ausgestattet, wenn mindestens einen Hauptverteiler im Kreis aufgerüstet wurde, um Breitbandzugang zu erlauben. Wir berücksichtigen bei der Berechnung verschiedene Besonderheiten: Mehrere Hauptverteiler können in einem Kreis installiert sein, Hauptverteiler an den Kreisgrenzen stellen nicht nur den Zugang für Haushalte und Unternehmen in diesem Kreis zur Verfügung sondern auch für Kunden in den benachbarten Kreisen, und Änderungen in den Kreisgrenzen über die Zeit müssen berücksichtigt werden.

Auf Branchenebene finden wir einen signifikant positiven Einfluss der Breitbandverfügbarkeit auf Gründungsintensitäten in den Hightech-Branchen wie Software und wissensintensiven Dienstleistungen. Im Gegensatz dazu existiert kein Einfluss, wenn wir alle Branchen zugleich betrachten. Darüber hinaus folgen die anderen Infrastrukturvariablen den Ergebnissen, die aus der Literatur bekannt sind. Wir zeigen folglich, dass ein weiterer Einflussfaktor für Gründungstätigkeit eine Rolle spielt. Unsere Ergebnisse stützen somit die aktuelle Breitbandinitiative in den europäischen Ländern. 


\title{
The Effect of Broadband Infrastructure on Entrepreneurial Activities: The Case of Germany
}

\author{
Diana Heger, Miriam Rinawi, Tobias Veith
}

\begin{abstract}
This paper investigates whether the local infrastructure favours entrepreneurial activities. Besides the physical and knowledge infrastructure we take into account a county's broadband availability by building an index which accounts for county-related specificities. We find that broadband availability fosters entrepreneurial activities particularly in high-tech sectors for which efficient ways of knowledge transfer is crucial.
\end{abstract}

JEL Codes: 018, L 26, R11

Key Words: broadband provision, physical and knowledge infrastructure, local entrepreneurial activities

Adress: $\quad$ Centre for European Economic Research (ZEW)

L 7, 1

68161 Mannheim

phone: +49-621-1235-382

email: heger@zew.de 


\section{Introduction}

Entrepreneurial activity is often seen as the backbone of a sustainable and growing economy. Despite their prospective global effects one of the most important determinants of new ventures' creation, success and survival are the local settings (Reynolds et al., 1994). The most famous example for a region with most favourable characteristics, that have fostered the creation of a number of successful world-leading companies, is the Silicon Valley (see Audretsch (1998) for a broader discussion).

One local characteristic that may drive the decision to establish a firm in a specific region is the supply of infrastructure. Infrastructure provision and infrastructure quality have been repeatedly identified as key drivers for firm foundations and subsequent economic growth (Nerlinger, 1996; Almus et al., 2001; Engel and Fier, 2000). Infrastructure important for entrepreneurial activity may take different forms and functions. First, trade and industrial growth require physical infrastructure like streets, rails and waterways. Second, particularly for knowledge- and technology-based ventures the knowledge infrastructure is crucial. Public research facilities like universities and institutes may be incubators in that entrepreneurs may benefit of information and knowledge spillovers. Finally, an additional type of knowledge spillovers may foster local entrepreneurial activities: the local business community. Those networks may help create specific and tacit business knowledge and contacts which may be vital for entrepreneurial firms (Audretsch, 1998; Almus et al., 2001).

However, the development of broadband infrastructure and, in particular, the technological progress in broadband infrastructure quality during the last decade motivated a discussion about the requirements of physical disposability and proximity to universities or the concentration of knowledge to establish new companies. First, it is said that new broadband infrastructure reduces the necessity of physical proximity as information and also knowledge could be transmitted through broadband infrastructures which makes physical proximity to knowledge "incubators" dispensable. However, distinguishing the dissemination of information and knowledge Audretsch (1998) argues that information flows are accelerated by internet infrastructure whereas the flow and the increase of knowledge requires personal contact as it is to a far extent generated in a tacit way. Audretsch et al. (2003) conclude that geographic proximity may be important for accessing the human capital embodied in university graduates who may serve as a spillover mechanism (see also Czarnitzki and Hottenrott, 2009). Second, taking broadband as a virtual marketplace and an infrastructure for customer contact, its roll-out and the increase of quality is a requirement for firm formations. Forman et al. (2005) show that in particular IT-producing industries' success less depends 
on local drivers. In contrast, IT-using industries are more sensitive to local cost drivers and regional coverage.

The impact of infrastructural endowment has not been intensively investigated so far, although it has been acknowledged that boadband infrastructure is a prerequisite in particular for high tech venture growth (Venkataraman, 2004). By dividing infrastructure types Andersson et al. (1990) find that telecommunication infrastructure has the same positive effects on a region's productivity as transportation infrastructure. Moreover, earlier studies on the impact of telecommunication infrastructure on economic growth have identified a significant influence on economic growth in developed countries (inter alia Röller and Waverman, 2001, Koutroumpis, 2009, Brynjolfsson and Saunders, 2010). Czernich et al. (2009) analyzed the effects of broadband infrastructure for a sample of OECD countries and find that GDP per capita is 2.7 to 3.9 percent higher after the introduction of broadband internet. Taking into account both direct and indirect effects of telecommunications, the European Commission estimates that 40 percent of 2007 EU economic growth could be dedicated to telecommunications. However, such estimates are typically based on aggregated data analyses and use approximated measures. Although the importance of telecommunications as a new driver for economic growth is known, growth drivers are hardly disentangled but are assumed as part of a "black box" structure.

Following the findings of the previous analyses it is thus compulsory to take a closer look at the role of telecommunication infrastructure not only as a direct driver of economic growth. Moreover, due to the strong divergence between EC estimates and scientific measures of the direct impact of telecommunications on economic growth, we concentrate on the micro data level of company foundations and analyze the impact of broadband availability on this growth driver in a more disaggregated approach. In doing so, we want to provide more detailed insights into the importance of high-speed internet availability for company foundations. Exploring which factors enhance or impede founding rates is undoubtedly of great interest, having also crucial policy implications (Storey and Tether, 1998). Therefore, we additionally separate ventures based on their industrial sector as we assume particularly high tech companies to be more dependent on high-speed internet access than medium and low tech ventures.

In contrast to more established businesses, start-ups do not require leased-line access with continuous high-speed internet access. Instead, at the early beginnings internet access could be usually based on standard broadband lines and, if necessary, will be turned to symmetric leased-lines when business continues to grow. In consequence, for the analysis 
of the broadband-venture-relation we concentrate on broadband availability and consider the consequences on regional venture activities. Broadband availability is thus explained by high-speed internet roll-out on county-level basis. Single main distribution frames (MDFs) hardly cover one county but multiple MDFs are installed and serve areas which also overlap multiple counties. As MDFs were "upgraded" sequentially, not all households in a county were able to demand broadband at the same point in time. We have built an indicator which measures broadband penetration taking into account alternative individual aspects. The more lines in a county are connected to broadband-capable MDFs the higher is the broadband indicator in this county.

Using a county-year panel structure we consider the impact of broadband availability on company foundations and control for standard impact factors on venture activities. On sector level, we find a significantly positive influence of broadband availability on founding intensities in software and technology-intensive services (knowledge-intensive services). In contrast, no influence exists for other sectors. Moreover, other infrastructural drivers of founding activities follow the results known from the literature. In consequence, our study provides evidence for an additional driver of entrepreneurial activities which supports the current broadband initiative in European countries and which also supports the effort to increase high-tech companies providing them with an adequate high-speed data infrastructure.

The paper is organized as follows: In Section 2 we describe the importance of infrastructural drivers for founding activities. In this context, we embed telecommunications infrastructure as a complementing platform which supports founding activities and, based on the literature, we derive hypotheses on the influence of infrastructure as a whole and telecommunications infrastructure in particular on founding activities. Subsequently, in Section 3 we provide detailed insights into our dataset. First, we describe the alternative data sources and limitations on the dataset. Afterwards, we derive our broadband-penetration indicator and discuss key challenges on its construction. Based on descriptive statistics of our dataset we highlight central aspects of broadband roll-out and entrepreneurial activities. In Section 4 we describe our estimation approaches, provide the estimation results and discuss them. Section 5 concludes the paper and provides an outlook on further steps which could complement our analysis. 


\section{Broadband - a third incubator infrastructure for ventures?}

Complex innovations within the telecommunication sector during the 1990 s initiated a discussion about changes of the traditional roles of physical and knowledge infrastructures as a prerequisite for ventures. From an a-priori perspective, broadband infrastructure opens access to information and knowledge and simultaneously facilitates the connection to customers and suppliers. In consequence, broadband infrastructure in line with the internet has been considered as a complementary venture promoter besides the traditional infrastructures. Even today, the European Commission in line with national governments expects broadband to be one of the key drivers for economic growth and supports broadband rollout all across Europe with varying state aid projects. However, due to missing data on ventures and also on broadband roll-out the impact of broadband as a driver for ventures (and also for other measures of growth) has not been analyzed in detail. As micro-data was missing for academic analysis, studies on the national level were implemented which can only partially isolate the "broadband effect" on growth drivers due to aggregation. Contributing to current discussions in line with the European Digital Agenda and national initiatives for upgrading existing broadband infrastructures, we analyze the influence of broadband as a third key infrastructure for regional venture activities besides the traditional physical and knowledge and information infrastructures. In contrast to prior studies, we take a microperspective which allows for in-depth considerations of the link between ventures in various sectors and broadband availability.

The rates of firm creation vary strongly across regions. Regions are heterogeneous in terms of agglomeration and transport connections, and thus, differ with respect to determinants affecting firm formation and growth. In particular, it is commonly agreed in the literature that key drivers exist which enhance regional entrepreneurial activities. Standard venture "promoters" can be classified into physical infrastructure and knowledge infrastructure. Physical infrastructures such as train stations, motorway connections or waterways are particular prerequisites for lower- and medium-tech industries. Bartik (1985), Egeln et al. (1997) and Nerlinger (1996) find a positive impact of alternative physical infrastructure measures on founding activities. In particular Nerlinger (1996) confirms a positive impact of motorway accesses also for higher-tech, but not for high-tech industries. However, as discussed in Steil (1999) for physical infrastructures, a key challenge for the analysis of the impact of infrastructure on entrepreneurial activities are adequate measures at a disaggregated level which enable the isolation of the relevant effect from other influences, an issue further discussed in the analysis of this paper. 
While physical infrastructures are a key driver for entrepreneurial activities in multiple industries ranging from low-tech to higher-tech, more recent studies identify knowledge infrastructures such as universities and research centers as an important driver for higher and high-tech industries. Information and knowledge creation attract companies with a higher requirement of own or foreign research activities as existing R\&D facilities enable scale effects based on the available R\&D infrastructure (Anselin et al. 1997, 2000, Fischer and Varga 2003, Varga 2000, 2001). The close proximity and collaborations between research institutes and private research activities build the playing field for ventures based on a profound level of knowledge and research results at the most recent stage of research. Thus, close relations of founders to research institutes and highly qualified employees familiar with most recent research techniques and results positively affect entrepreneurial activities around universities and think tanks (Bade and Nerlinger 1998, Engel and Metzger 2006). Both geographic intra-industry proximity and the close connection to research centers promote tacit knowledge transfers which is a particular success driver the more specialized the industry and the higher skilled employees (Breschi and Lissoni 2001, Feldman 1999, Gertler 1995). In consequence, the effectiveness of potential spillovers is a key driver for regional venture success (Audretsch and Feldman 1996).

The upcoming internet enabled particular chances and opportunities for smaller companies with respect to new business models or supplier and customer contacts. Famous examples of new business models are Google, Ebay or Facebook which would not exist without the fast development of transmission technology during the last two decades. Apart from these highlighting examples, high-speed internet access also provides the platform for virtual market places for more traditional sectors and opens new channels for supplier and customer contacts. E.g., high-speed internet access enables "virtual - traditional" market discrimination strategies to get more market and competitor information, to address further supplier and customer groups and, thus, to gain a faster and better understanding of dynamic aspects of competition. These comprehensive changes in communications support the position that high-speed internet access complements traditional infrastructures as a third channel promoting entrepreneurial activities. In consequence, venture rates should benefit from broadband access.

H1: Broadband infrastructure availability positively affects regional venture rates.

While academics agree that physical and knowledge infrastructures serve differing venture groups and partially cross-fertilize each other, the impact of broadband as a new infrastructure is unclear. As described in line with $\mathrm{H} 1$ broadband is expected to influence venture 
rates in a positive way. Following Audretsch (1998), one has to distinguish between the impact on knowledge infrastructure and information infrastructure: Knowledge formation, in particular in high-tech and research-intensive industries, requires close proximity and direct personal contact as creation and motivation are based on individual skills and the ability and the possibility to interact closely. Thus, only a weak link of broadband access should exist with the impact of knowledge infrastructure on entrepreneurial activities. In contrast, broadband infrastructure accelerates information flows and consequently the process of getting established information. Thus, it is most important to distinguish affected industries.

As described above, ventures in lower- and medium-tech industries strongly depend on physical infrastructures, whereas higher- and high-tech ventures benefit from knowledge infrastructure and, simultaneously, from spillovers of companies in the same industry. While these two infrastructure types mainly address venture inputs, broadband infrastructure influences both input and output components. Broadband enables access to information independent from a founder's location and the location of information as an input and, simultaneously, provides a channel for customer contact also independent from eithers' location. Taking into account that information and knowledge are particular inputs to higher- and high-tech products, we expect a stronger positive effect of broadband infrastructure as a driver for higher- and high-tech ventures than for lower-tech ventures.

H2: Broadband infrastructure more strongly affects sectors which are more dependent on faster information exchange.

\section{Data \& Descriptive Statistics}

We test the hypotheses derived in the previous section using data from alternative sources. The key advantage of our analysis is the data aggregation level. First, the availability of regional level data provides the opportunity to isolate regional differences instead of country diversity which makes our results much more robust in this respect. Second, due to the disaggregated data availability we are able to consider well-defined industry differences as industry data is prepared from individual company information which allows for in-depth considerations of subcategories per industry. For the analysis of the broadband impact on venture activities, we combine company information, regional information and broadband rollout information from alternative sources.

The starting point of our dataset is the Mannheim Enterprise Panel (MUP). The MUP is carried out in cooperation with Creditreform, the largest credit rating agency in Germany. Creditreform collects comprehensive data on German firms on the individual level provided twice 
a year to the Centre for European Economic Research (ZEW). From this individual company information, the MUP is the baseline for the calculation of alternative entrepreneurial rates at different regional and industry levels. Due to the known relation of companies in this database to total firm population in Germany, we are able to extrapolate the data for a representative picture of German firms on timely, geographic and sector specific level.

Moreover, the dataset enables the analysis of ventures as detailed firm information is available about changes in activities and the age of firms under scrutiny. In consequence, we are able to use representative, aggregated information on county-sector level to analyse the impact of alternative input factors on entrepreneurial activities at a strongly disaggregated regional level which enables us to sharply separate other regional input factors when explaining entrepreneurial activities. One particular challenge in regional company analyses is that regional influences rarely depend on county boundaries. For example, households' working places and homes are frequently at different places. Thus, highly industrialized regional areas are probably more attractive for ventures whereas city centers or more rural areas are more attractive for living. To control these issues, we compare simple county-level analyses with analyses based on economically more meaningful regional indicators (Raumordnungsregionen) which particularly take into account the flows of commuters. Moreover, as population and industry distributions vary not only across but also within counties, this affects broadband roll-out, which is based on local or even MDF regional density measures.

To this data set we merge further county-specific information using different sources. From the German Federal Statistical Office (Statistisches Bundesamt) we include data regarding the percentage of employees in firms with more than 249 employees who are subject to social security contributions and the variation of gross value added in industrial sectors and service sectors. Information on permantly unemployed persons (for the calculation of shortterm unemployment) and the structure of urban development are taken from the Federal Office for Building and Regional Planning (Bundesamt für Bauwesen und Raumordnung). The structure of urban development helps us to identify counties which can be counted as agglomerations, regional metropolis, middle-order centers or rural areas.

In order to adequately picture the number of motorway interchanges within a county we used OpenStreetMap to identify the interchanges and the Geographical Information System (GIS) to locate them within the counties. Furthermore, we counted the number of longdistance train stations in a county by using the route map (Streckenplan) of the year 2010 
provided on the Deutsche Bahn website ${ }^{1}$. In order to get the period of when the stations held their status all indicated long-distance train stations were manually investigated by checking the respective city's website. To capture the knowledge infrastructure we refer to minimal distance to a public research institute or university focusing on the areas of mathematics, computer science, natural science and engineering.

Table 1: Descriptive statistics

\begin{tabular}{|c|c|c|c|c|}
\hline & Mean & Std. Dev. & Min. & Max. \\
\hline Entrepreneurial activity (all industries) & 0.425 & 0.110 & 0.179 & 0.824 \\
\hline $\begin{array}{l}\text { Entrepreneurial activity (high-tech indus- } \\
\text { tries) }\end{array}$ & 0.029 & 0.013 & 0.000 & 0.077 \\
\hline $\begin{array}{l}\text { Entrepreneurial activity (technology-oriented } \\
\text { manufacturing) }\end{array}$ & 0.004 & 0.003 & 0.000 & 0.015 \\
\hline $\begin{array}{l}\text { Entrepreneurial activity (technology-oriented } \\
\text { services) }\end{array}$ & 0.025 & 0.012 & 0.000 & 0.071 \\
\hline Entrepreneurial activity (software) & 0.007 & 0.005 & 0.000 & 0.027 \\
\hline Broadband index & 0.867 & 0.209 & 0.000 & 1.000 \\
\hline Distance MINT & 0.203 & 0.207 & 0.000 & 1.066 \\
\hline Log(moterway interchanges) & 3.617 & 0.970 & 0.000 & 5.759 \\
\hline Long-distance train stations & 0.568 & 0.732 & 0 & 5 \\
\hline $\begin{array}{l}\text { Share of employees in firms > } 249 \text { employ- } \\
\text { ees }\end{array}$ & 0.274 & 0.122 & 0.048 & 0.758 \\
\hline $\begin{array}{l}\Delta \text { growth rate of gross value added in sec- } \\
\text { ondary sector }\end{array}$ & 0.000 & 0.044 & -0.147 & 0.159 \\
\hline $\begin{array}{l}\Delta \text { growth rate of gross value added in tertiary } \\
\text { sector }\end{array}$ & -0.003 & 0.020 & -0.054 & 0.050 \\
\hline $\begin{array}{l}\text { Share of short-time unemployed per em- } \\
\text { ployees }\end{array}$ & 0.077 & 0.043 & 0.016 & 0.240 \\
\hline Eastern Germany & 0.184 & 0.388 & 0 & 1 \\
\hline Share of employees in manufacturing & 0.209 & 0.091 & 0.029 & 0.571 \\
\hline $\begin{array}{l}\text { Share of employees in business related ser- } \\
\text { vices }\end{array}$ & 0.131 & 0.050 & 0.059 & 0.312 \\
\hline Ich-AG & 0.776 & 0.077 & 0.394 & 0.982 \\
\hline Agglomeration (> 300,000 inhabitants) & 0.376 & 0.485 & 0 & 1 \\
\hline $\begin{array}{l}\text { Share of inhabitants reaching next regional } \\
\text { metropolis within } 30 \text { minutes of driving }\end{array}$ & 0.676 & 0.384 & 0.000 & 1.000 \\
\hline
\end{tabular}




\section{Regional broadband penetration}

The central variable of our analysis is the broadband indicator. Broadband penetration is measured on a county basis. A county is equipped with broadband if at least one MDF in the county is upgraded to allow for broadband access. However, multiple difficulties come into play when defining broadband penetration of a county. On the one hand, multiple MDFs are installed within one county, and on the other hand, MDFs at county boundaries do not only provide access to households and companies in that county but also to connected consumers in the neighboring counties. A third aspect to be taken into account is the change of county boundaries across time. In subsequence of the German re-unification a number of counties mostly in Eastern Germany have been reorganized due to declining population or due to administrative expenses. Resulting adjustments in counties were partially implemented between 2000 and 2005 which we have to take into account when calculating broadband penetration as it changes the penetration index although both the number of consumers per MDF and broadband availability remained unchanged.

In the following, we derive the construction of the broadband penetration index and our approach to handle changes in the aforementioned aspects. As MDFs provide telecommunication line access to a varying number of customers, we cannot easily use the number of upgraded MDFs per total MDFs in an area but we have to take into consideration the number of subscriber lines. ${ }^{2}$ Thus, our index is independent of the number of MDFs in a county. If an MDF with a major share of subscriber lines in a county is upgraded whereas all other MDFs are not, we observe a jump in broadband penetration in the year of upgrade. In contrast to this, if an MDF in county $j$ with a major share of subscribers in the neighboring county $-j$ is upgraded, this predominantly affects county $-j$ s broadband penetration.

Unfortunately, we only know the area code of the upgraded MDF and the number of subscriber lines in the area but we do not exactly know, which subscriber line is connected to which MDF. First, in most cases multiple MDFs share the same area code. Second, areas overlap county boundaries and cannot be assigned precisely. As MDFs belong to one par-

\footnotetext{
2 Please note that we have no information on broadband quality. Hence, we do not know the actually installed broadband quality and we cannot measure line losses due to the length of subscriber lines.
} 
ticular area we first calculate the weight of the MDF in the area using the number of subscriber lines:

$$
s h b b_{m t}=\frac{\sum_{a} \# s l_{a m t}}{\# s l_{m t}}
$$

with $\sum_{a} \# s l_{a m t}$ as the number of subscriber lines at upgraded MDFs in area $m$ at time $t$ and $\# s l_{m t}$ is the total number of subscriber lines connected to both upgraded MDFs and standard MDFs in this area. The largest unit, which can be linked to both areas with one area code and counties, is municipalities as all subscriber lines in municipalities have the same area code. Therefore, we use the number of households in each municipality (as they are the major consumers for broadband), distribute broadband penetration of the area to counties and calculate the average broadband penetration based on the areas covering the county as follows:

$$
P I_{i t}=\sum_{n} \frac{\# h h_{i n t}}{\# h h_{n t}} \operatorname{shb} b_{n t}
$$

For each county $i$ and each area $m$ with the same area code ${ }^{3}$, we use the number of households $\# h h_{i m t}$ in period $t$. Changes of county boundaries over time force us to calibrate our calculations to a base year. We use 2004 as this base year and re-adjust the penetration index thus "correcting" for changes in county boundaries. As the available number of broadband upgrades covers total year information and as we want to use average broadband upgrades, the per-year information is calculated for July $1^{\text {st }}$ in each year.

\section{Empirical Results}

In order to test whether regional entrepreneurship is influenced by different infrastructure characteristics of the county we estimate OLS regressions for the entrepreneurial intensity which is defined as the number of newly established firms in a year divided per 10.000 employees in a specific county. Furthermore, we calculate the entrepreneurial intensities for different industry clusters. The first column of Table 2 displays the results for all sectors. The second column shows the coefficients for a subset: high-tech manufacturing and services,

${ }^{3} n$ is a continuous index 
whereas column 3 and 4 depict the results for R\&D-intensive manufacturing and technologyoriented services respectively. In the last column, we look at the impact factors for the software sector which is a subset of the technology-oriented services.

Table 2: OLS regression results

\begin{tabular}{|c|c|c|c|c|c|c|c|c|c|c|}
\hline \multirow[b]{2}{*}{ Broadband index } & \multicolumn{2}{|c|}{ All sectors } & \multicolumn{2}{|c|}{ All high-tech } & \multicolumn{2}{|c|}{ R\&D manu } & \multicolumn{2}{|l|}{ Tech serv. } & \multicolumn{2}{|c|}{ Software } \\
\hline & $\begin{array}{r}0.082 \\
(0.036)\end{array}$ & $\star \star$ & $\begin{array}{r}0.013 \\
(0.003)\end{array}$ & $\star \star \star$ & $\begin{array}{r}0.002 \\
(0.001)\end{array}$ & $\star \star$ & $\begin{array}{r}0.006 \\
(0.002)\end{array}$ & $\star \star \star$ & $\begin{array}{r}0.004 \\
(0.001)\end{array}$ & $\star \star \star *$ \\
\hline Distance MINT & $\begin{array}{r}-0.026 \\
(0.027)\end{array}$ & & $\begin{array}{r}-0.013 \\
(0.003)\end{array}$ & $\star * \star$ & $\begin{array}{r}-0.001 \\
(0.001)\end{array}$ & & $\begin{array}{r}-0.008 \\
(0.002)\end{array}$ & $\star \star \star *$ & $\begin{array}{r}-0.004 \\
(0.001)\end{array}$ & $\star \star \star *$ \\
\hline $\begin{array}{l}\text { Log(moterway } \\
\text { interchanges) }\end{array}$ & $\begin{array}{r}0.007 \\
(0.008)\end{array}$ & & $\begin{array}{r}0.001 \\
(0.001)\end{array}$ & & $\begin{array}{r}0.000 \\
(0.000)\end{array}$ & & $\begin{array}{r}0.000 \\
(0.000)\end{array}$ & & $\begin{array}{r}0.000 \\
(0.000)\end{array}$ & * \\
\hline $\begin{array}{l}\text { Long-distance } \\
\text { train stations }\end{array}$ & $\begin{array}{r}0.026 \\
(0.008)\end{array}$ & $\star \star \star \star ~$ & $\begin{array}{r}0.003 \\
(0.001)\end{array}$ & $\star \star \star$ & $\begin{array}{r}-0.000 \\
(0.000)\end{array}$ & & $\begin{array}{r}0.002 \\
(0.001)\end{array}$ & $\star \star \star *$ & $\begin{array}{r}0.001 \\
(0.000)\end{array}$ & $\star \star *$ \\
\hline $\begin{array}{l}\text { Share of employ- } \\
\text { ees in firms }>249 \\
\text { employees }\end{array}$ & $\begin{array}{r}-0.019 \\
(0.077)\end{array}$ & & $\begin{array}{l}-0.010 \\
(0.006)\end{array}$ & & $\begin{array}{r}-0.003 \\
(0.001)\end{array}$ & $\star \star \star$ & $\begin{array}{r}-0.007 \\
(0.004)\end{array}$ & & $\begin{array}{r}0.000 \\
(0.002)\end{array}$ & \\
\hline $\begin{array}{l}\Delta \text { growth rate of } \\
\text { gross value add- } \\
\text { ed in secondary } \\
\text { sector }\end{array}$ & $\begin{array}{r}0.018 \\
(0.047)\end{array}$ & & $\begin{array}{l}-0.002 \\
(0.006)\end{array}$ & & $\begin{array}{r}-0.000 \\
(0.002)\end{array}$ & & $\begin{array}{r}0.001 \\
(0.004)\end{array}$ & & $\begin{array}{r}-0.002 \\
(0.003)\end{array}$ & \\
\hline $\begin{array}{l}\Delta \text { growth rate of } \\
\text { gross value add- } \\
\text { ed in tertiary } \\
\text { sector }\end{array}$ & $\begin{array}{l}-0.118 \\
(0.105)\end{array}$ & & $\begin{array}{l}-0.010 \\
(0.016)\end{array}$ & & $\begin{array}{r}0.002 \\
(0.005)\end{array}$ & & $\begin{array}{r}-0.008 \\
(0.012)\end{array}$ & & $\begin{array}{r}-0.008 \\
(0.006)\end{array}$ & \\
\hline $\begin{array}{l}\text { Share of short- } \\
\text { time unemployed } \\
\text { per employees }\end{array}$ & $\begin{array}{l}-0.904 \\
(0.414)\end{array}$ & $\star \star$ & $\begin{array}{l}-0.218 \\
(0.032)\end{array}$ & $\star \star \star *$ & $\begin{array}{r}-0.028 \\
(0.007)\end{array}$ & $\star \star \star$ & $\begin{array}{r}-0.122 \\
(0.023)\end{array}$ & $\star \star \star$ & $\begin{array}{r}-0.067 \\
(0.012)\end{array}$ & $\star \star \star$ \\
\hline Eastern Germany & $\begin{array}{r}0.040 \\
(0.054)\end{array}$ & & $\begin{array}{r}0.008 \\
(0.006)\end{array}$ & & $\begin{array}{l}-0.000 \\
(0.001)\end{array}$ & & $\begin{array}{r}0.009 \\
(0.004)\end{array}$ & ** & $\begin{array}{r}-0.001 \\
(0.002)\end{array}$ & \\
\hline $\begin{array}{l}\text { East * Un- } \\
\text { employment }\end{array}$ & $\begin{array}{r}0.417 \\
(0.502)\end{array}$ & & $\begin{array}{r}0.057 \\
(0.047)\end{array}$ & & $\begin{array}{r}0.015 \\
(0.009)\end{array}$ & * & $\begin{array}{r}0.008 \\
(0.034)\end{array}$ & & $\begin{array}{r}0.039 \\
(0.016)\end{array}$ & $\star \star$ \\
\hline Constant & $\begin{array}{r}0.394 \\
(0.053)\end{array}$ & $\star \star \star$ & $\begin{array}{r}0.033 \\
(0.005)\end{array}$ & $\star \star \star$ & $\begin{array}{r}0.005 \\
(0.001)\end{array}$ & 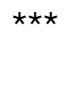 & $\begin{array}{r}0.022 \\
(0.003)\end{array}$ & $\star \star \star$ & $\begin{array}{r}0.006 \\
(0.002)\end{array}$ & $\star \star \star$ \\
\hline Year dummies & & & & & inclu & ded & & & & \\
\hline No. of obs. & 1244 & & 1250 & & 1250 & & 1247 & & 1251 & \\
\hline log Likelihood & 1100.43 & & 3842. & & 5557.0 & & 4201.68 & & 5047.4 & \\
\hline F(all) & 38.45 & $\star \star \star$ & 16.20 & $\star \star \star$ & 3.55 & $\star \star \star$ & 12.38 & $\star \star \star$ & 13.02 & $\star \star \star$ \\
\hline
\end{tabular}

The focus of our analyses is the regional endowment with infrastructure. We find that the broadband index has a positive impact on all industry clusters, i.e. the more developed the supply with broadband infrastructure in a region the higher the entrepreneurial activity. With respect to the knowledge infrastructure reflected by the distance to the next university providing mathematics, informatics, natural sciences and engineering (MINT) we conclude that the distance is negatively linked to the entrepreneurial activity in technology-oriented ser- 
vices including software. This result shows the crucial impact of knowledge for those industries. Finally, we control for the physical infrastructure by relating regional entrepreneurship to the number of motorway interchanges and the number of long-distance train stations. We find no significant effect of motorway interchanges on entrepreneurial activity which hints at the fact that Germany already provided a tight net of motorways. But we find a significantly positive impact of train stations except for R\&D-intensive manufacturing. These effects do not vanish when controlling for specific regional characteristics which may be gathered by the number of train stations. Particularly for service industries the possibility to quickly bridge long distances seems to be crucial, e.g. for maintenance of customer contacts.

Since the provision of broadband may follow specific regional characteristics such as the population density we run several robustness checks which are all presented in the Appendix. The first robustness check includes three measures reflecting different indicators for the population density. The second robustness check also reflects the shares of employees working in manufacturing and business-related services. Third, we also control for a change in entrepreneurial policy: In the year 2003, the German government established a new program for unemployed. They received a certain amount of funding if they got self-employed. Subsequently, the number of newly established firms rose significantly. Fourth, we re-run the regressions including indicators for regional planning units (Raumordnungsregionen) which better reflect the flows of commuters and trading area, particularly surrounding large cities. ${ }^{4}$ Finally, we run tobit regressions because mainly entrepreneurial activities in hightech sectors depict an uneven regional distribution resulting in a substantial amount of zero values for some regions. For all high-tech industry clusters $^{5}$ (i.e. columns 2 to 5 ), we find that the results regarding the regional availability of broadband are robust so that we can conclude that the provision of broadband was a crucial factor driving the regional distribution of high-tech entrepreneurship. However, if we look at all sectors the coefficients of the broadband index turn to be insignificant (see Table 3 in Appendix). Hence, the effect of broadband provision captured other regional characteristics like population density. When controlling for those characteristics the effect is no longer existent. Hence, broadband does not have an overall effect on the entrepreneurial activity. When looking at high-tech industries the effect of broadband provision persists even when controlling for other regional characteristics.

\footnotetext{
${ }^{4}$ These robustness checks are not provided in the Appendix. They can be obtained upon authors' request.

${ }^{5}$ In the Appendix we provide tables displaying all robustness checks for the different industry clusters. Table 3 shows the robustness checks for all industries which corresponds to column 1 in Table 2 . The results of Table 4,Table 5,Table 6 and Table 7 correspond to the robustness checks of column 2, 3, 4 and 5 respectively.
} 
Consequently, broadband provision was a driver of regional entrepreneurial activity in hightech industries during the observed period.

With respect to the control variables the most striking result is that the higher the local share of unemployed the lower is the local entrepreneurial activity. This results holds when controlling for the Ich-AG funding scheme which aimed at fostering the transfer to selfemployment particularly for unemployed. Obviously the effect of this funding scheme on regional entrepreneurial activity is positive. Whether the county is more rural or metropolitan also has an impact on the entrepreneurial activity. Agglomerations are more favourable for entrepreneurial activities in R\&D-intensive manufacturing and technology-intensive services. Whereas technology-intensive services and software firms are more often established in close to regional metropolis areas where the prices for commercial premises are expected to be lower than in metropolitan regions. When looking at the share of employees in manufacturing and service industries they both have positive effects on entrepreneurial activities in the respective industry clusters.

\section{Conclusion}

This paper contributes to the discussion of regional differences in entrepreneurial activity as it links the entrepreneurial rate to the locally available infrastructure. The focus lies on the local broadband provision and its impact on entrepreneurial activity- The development and regional penetration of broadband technology may influence the entrepreneurial culture in two ways: First, it opens doors for new business models like Facebook and Ebay. Second, it allows for new virtual marketplace as well as new ways in customer attraction, communication and marketing.

Infrastructure may have different facets of which broadband provision is one. Hence, we contrast the impact of the broadband infrastructure with more "traditional" definitions of infrastructure. One is the physical infrastructure which is said to have a crucial impact on the development of trade and industrial growth. Physical infrastructure comprises motorway interchanges and long-distance train stations. Besides the physical infrastructure knowledge infrastructure may play a crucial role, particularly for high-tech industries as the proximity to universities and research facilities facilitates knowledge spillovers and may serve as incubators. Furthermore, local businesses also complement knowledge spillovers by circulating predominantly tacit knowledge in their networks. Both dimensions of spillovers may favour regional entrepreneurial activities. 
Using county-level data on entrepreneurial rates, physical knowledge and broadband infrastructure combining information of different sources we try to answer the following questions: Does broadband infrastructure availability positively affect regional entrepreneurial rates and is its impact stronger for sectors which are more dependent on faster information diffusion and exchange like high-tech industries? To answer these questions we build a broadband penetration index on the county-level which accounts for different issues: one single main distribution frame (MDF) does hardly cover the need of one entire county. Moreover, the index controls for the fact if multiple MDFs exist in a county and allows for the possibility cross-boundary access if the MDF is located at the boundary. Finally, it takes into account all changes in county boundaries due to political decisions.

Results are presented for all industries but also for high-tech industries and specific hightech clusters where broadband expansion is assumed to have highest impact because of the inherent reliance on knowledge and its efficient transfer. We find that broadband infrastructure is particularly crucial for entrepreneurial activities in high-tech industries over all high-tech industry clusters. The effect of broadband availability may be overlaid by other regional characteristics but the effect on high-tech industries is robust when controlling for different regional measures. The effect of broadband availability on the entrepreneurial activities in all industries however vanishes when controlling for other regional factors, i.e. the broadband effect is overlaid by regional characteristics.

Infrastructure including efficient knowledge transfer infrastructure is subject to activities of locally and nationally operating decision makers. Hence, relying on the results of this study measures can be implemented in shaping the prerequisites of a vivid entrepreneurial environment even if the regional endowments do not seem to be favourable at first glance. 


\section{References}

Almus, M., Egeln, J., \& Engel, D. (2001). Determinanten regionaler Unterschiede in der Gründungshäufigkeit wissensintensiver Dienstleister. Jahrbuch für Regionalwissenschaft, 21, 25-51.

Anselin, L., Varga, A., \& Acs, Z. J. (2000): Geographical spillovers and university research: A spatial econometric perspective. Growth and Change 31 (4): 501-515.

Anselin, L., Varga, A., \& Acs, Z. J. (1997): Local geographic spillovers between university research and high technology innovations. Journal of Urban Economics 42 (3): 422 448.

Audretsch, D. B., Lehmann, E., \& Warning, S. (2003): University spillovers: strategic location and new firm performance. Centre for Economic Policy Research, Discussion Paper Series No. 3837.

Audretsch, D. B. (1998). Agglomeration and the location of innovative activity. Oxford Review of Economic Policy 14, 18-29.

Audretsch, D. B., \& Feldman, M. P. (1996): R\&D spillovers and the geography of innovation and production. The American Economic Review 86 (3): 630-640.

Bade, F.-J., \& Nerlinger, E. (2000): The spatial distribution of new technology-based firms: empirical results for West-Germany. Regional Science 79: 155-176.

Bartik, T. J. (1985). Business Location Decisions in the United States: Estimates of the Effects of Unionization, Taxes, and Other Characteristics of States. Journal of Business and Economic Statistics 3. 14-22.

Breschi, S., \& Lissoni, F. (2001): Knowledge spillovers and local innovation systems: a critical survey. Industrial and Corporate Change 10: 975-1005.

Brynjolfsson, E., \& Saunders, A. (2010): Wired for innovation - how information technology is reshaping the economy. Cambridge (MA): The MIT Press.

Czarnitzki, D. \& Hottenrott, H. (2009). Are local milieus the key to innovation performance?. Journal of Regional Science 49, 81-112.

Czernich, N., O. Falk, T. Kretschmer und L. Woessmann (2011): Broadband Infrastructure and Economic Growth, Economic Journal, 121, 505-532.

Egeln, J., Licht, G., \& Steil, F. (1997): Firm foundations and the role of financial constraints. Small Business Economics 9: 137-150.

Engel, D., \& Fier, A. (2000): Does R\&D infrastructure attract high-tech start-ups? ZEW Discussion Paper No. 00-30. 
Engel, D., \& Metzger, G. (2006): Direct employment effects of new firms. Further empirical insights concerning the regional and technological dimension. In: Fritsch, M., \& Schmude, J. (Eds.): Entrepreneurship in the region. New York: Springer Science+Business Media.

Feldman, M. P. (1999): The new economics of innovations, spillovers and agglomerations: a review of empirical studies. Economics of Innovation and New Technology 8: 5-25.

Fischer, M., \& Varga, A. (2003): Spatial knowledge spillovers and university research: evidence from Austria. Annals of Regional Science 37(2): 303-322.

Forman, C., Goldfarb, A. \& Greenstein, S. (2005). How Do Industry Features Influence the Role of Location on Internet Adoption? Journal of the Association for Information Systems 6. 383-408.

Gertler, M. S. (1995): Being there: proximity, organization, and culture in the development and adoption of advanced manufacturing technologies. Economic Geography 71: 126.

Koutroumpis, P. (2009): The economic impact of broadband on growth: a simultaneous approach. Telecommunications Policy 33 (9): 471-485.

Nerlinger, E. (1996): Firm formation in high-tech industries: empirical results for Germany. ZEW Discussion Paper No. 96-07.

Reynolds, P. D., Storey, D. J., \& Westhead, P. (1994): Cross-national comparisons of the variation in new firm formation rates. Regional Studies 28: 443-456.

Röller, L.-H., \& Waverman, L. (2001): Telecommunications infrastructure and economic development. A simultaneous approach. The American Economic Review 91 (4): 909923.

Steil, F. (1999). Determinanten regionaler Unterschiede in der Gründungsdynamik - Eine empirische Analyse für die neuen Bundesländer. ZEW Wirtschaftsanalysen Band 24. Nomos, Baden-Baden.

Storey, D. J., \& Tether, B. S. (1998): Public policy measures to support new technology-based firms in the European Union. Research Policy 26 (9): 1037-1057.

Varga, A. (2001): Universities and regional economic development: does agglomeration matter? In: Johansson, B., Karlsson, C., \& Stough, R. (Eds.): Theories of Endogenous Regional Growth - Lessons for Regional Policies. Berlin: Springer Verlag.

Varga, A. (2000): Local academic knowledge spillovers and the concentration of economic activity. Journal of Regional Science 40 (2): 289-309.

Venkataraman, S. (2004): Regional transformation through technological entrepreneurship. Journal of Business Venturing (19): 153-167. 


\section{Appendix}

Table 3: Robustness checks for all industries

\begin{tabular}{|c|c|c|c|c|c|c|c|c|}
\hline \multirow[b]{2}{*}{ Broadband index } & \multicolumn{2}{|c|}{ Robust (1) } & \multicolumn{2}{|c|}{ Robust (2) } & \multicolumn{2}{|c|}{ Robust (3) } & \multicolumn{2}{|c|}{ Tobit } \\
\hline & $\begin{array}{r}0.033 \\
(0.036)\end{array}$ & & $\begin{array}{r}0.004 \\
(0.034)\end{array}$ & & $\begin{array}{r}0.010 \\
(0.035)\end{array}$ & & $\begin{array}{r}0.082 \\
(0.036)\end{array}$ & *夫 \\
\hline Distance MINT & $\begin{array}{r}0.039 \\
(0.029)\end{array}$ & & $\begin{array}{r}0.067 \\
(0.028)\end{array}$ & $\star \star$ & $\begin{array}{r}0.078 \\
(0.027)\end{array}$ & $\star \star \star$ & $\begin{array}{r}-0.026 \\
(0.027)\end{array}$ & \\
\hline $\begin{array}{l}\text { Log(moterway inter- } \\
\text { changes) }\end{array}$ & $\begin{array}{l}-0.003 \\
(0.008)\end{array}$ & & $\begin{array}{l}-0.006 \\
(0.007)\end{array}$ & & $\begin{array}{l}-0.002 \\
(0.006)\end{array}$ & & $\begin{array}{r}0.007 \\
(0.008)\end{array}$ & \\
\hline $\begin{array}{l}\text { Long-distance train } \\
\text { stations }\end{array}$ & $\begin{array}{r}0.026 \\
(0.008)\end{array}$ & $\star \star \star$ & $\begin{array}{r}0.012 \\
(0.007)\end{array}$ & * & $\begin{array}{r}0.014 \\
(0.007)\end{array}$ & $\star \star$ & $\begin{array}{r}0.026 \\
(0.008)\end{array}$ & 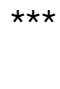 \\
\hline $\begin{array}{l}\text { Agglomeration } \\
(>300,000 \text { inhabi- } \\
\text { tants) }\end{array}$ & $\begin{array}{r}0.045 \\
(0.013)\end{array}$ & $\star \star \star$ & $\begin{array}{r}0.022 \\
(0.013)\end{array}$ & * & $\begin{array}{r}0.017 \\
(0.013)\end{array}$ & & & \\
\hline $\begin{array}{l}\text { Share of inhabi- } \\
\text { tants reaching next } \\
\text { regional metropolis } \\
\text { within } 30 \text { minutes } \\
\text { of driving }\end{array}$ & $\begin{array}{r}0.051 \\
(0.020)\end{array}$ & $\star \star \star$ & $\begin{array}{r}0.037 \\
(0.020)\end{array}$ & * & $\begin{array}{r}0.026 \\
(0.018)\end{array}$ & & & \\
\hline $\begin{array}{l}\text { Share of inhabi- } \\
\text { tants in municipali- } \\
\text { ties with } \\
<150 \text { inhabitants }\end{array}$ & $\begin{array}{l}-0.058 \\
(0.026)\end{array}$ & ** & $\begin{array}{l}-0.016 \\
(0.026)\end{array}$ & & $\begin{array}{l}-0.034 \\
(0.025)\end{array}$ & & & \\
\hline $\begin{array}{l}\text { Share of employees } \\
\text { in manufacturing }\end{array}$ & & & $\begin{array}{l}-0.062 \\
(0.092)\end{array}$ & & $\begin{array}{l}-0.144 \\
(0.089)\end{array}$ & & & \\
\hline $\begin{array}{l}\text { Share of employees } \\
\text { in business related } \\
\text { services }\end{array}$ & & & $\begin{array}{r}0.890 \\
(0.202)\end{array}$ & $\star \star \star *$ & $\begin{array}{r}0.747 \\
(0.195)\end{array}$ & $\star \star \star *$ & & \\
\hline Ich-AG & & & & & $\begin{array}{r}0.004 \\
(0.001)\end{array}$ & $\star \star \star *$ & & \\
\hline $\begin{array}{l}\text { Share of employees } \\
\text { in firms > } 249 \text { em- } \\
\text { ployees }\end{array}$ & $\begin{array}{r}-0.132 \\
(0.073)\end{array}$ & * & $\begin{array}{r}-0.144 \\
(0.068)\end{array}$ & ** & $\begin{array}{l}-0.093 \\
(0.068)\end{array}$ & & $\begin{array}{l}-0.019 \\
(0.077)\end{array}$ & \\
\hline $\begin{array}{l}\Delta \text { growth rate of } \\
\text { gross value added } \\
\text { in secondary sector }\end{array}$ & $\begin{array}{r}0.004 \\
(0.047)\end{array}$ & & $\begin{array}{r}0.013 \\
(0.046)\end{array}$ & & $\begin{array}{r}0.005 \\
(0.043)\end{array}$ & & $\begin{array}{r}0.018 \\
(0.047)\end{array}$ & \\
\hline $\begin{array}{l}\Delta \text { growth rate of } \\
\text { gross value added } \\
\text { in tertiary sector }\end{array}$ & $\begin{array}{l}-0.113 \\
(0.104)\end{array}$ & & $\begin{array}{l}-0.078 \\
(0.095)\end{array}$ & & $\begin{array}{l}-0.019 \\
(0.092)\end{array}$ & & $\begin{array}{l}-0.118 \\
(0.104)\end{array}$ & \\
\hline $\begin{array}{l}\text { Share of short-time } \\
\text { unemployed per } \\
\text { employees }\end{array}$ & $\begin{array}{l}-1.060 \\
(0.403)\end{array}$ & $\star \star \star$ & $\begin{array}{l}-0.763 \\
(0.381)\end{array}$ & $\star \star$ & $\begin{array}{r}-0.383 \\
(0.373)\end{array}$ & & $\begin{array}{r}-0.904 \\
(0.412)\end{array}$ & ** \\
\hline Eastern Germany & $\begin{array}{r}0.022 \\
(0.049)\end{array}$ & & $\begin{array}{r}-0.004 \\
(0.050)\end{array}$ & & $\begin{array}{l}-0.007 \\
(0.051)\end{array}$ & & $\begin{array}{r}0.040 \\
(0.054)\end{array}$ & \\
\hline $\begin{array}{l}\text { East * Unemploy- } \\
\text { ment }\end{array}$ & $\begin{array}{r}0.686 \\
(0.473)\end{array}$ & & $\begin{array}{r}0.600 \\
(0.454)\end{array}$ & & $\begin{array}{r}0.257 \\
(0.451)\end{array}$ & & $\begin{array}{r}0.417 \\
(0.499)\end{array}$ & \\
\hline Constant & $\begin{array}{r}0.467 \\
(0.058)\end{array}$ & $\star \star \star *$ & $\begin{array}{r}0.393 \\
(0.067)\end{array}$ & $\star \star \star *$ & $\begin{array}{r}0.057 \\
(0.083)\end{array}$ & & $\begin{array}{r}0.394 \\
(0.053)\end{array}$ & $\star \star \star *$ \\
\hline Year dummies & & & & Inclu & & & & \\
\hline
\end{tabular}




\begin{tabular}{lcccc} 
Sigma & & & $\begin{array}{c}0.100 \\
(0.004)\end{array}$ \\
\hline No. of obs. & 1244 & 1244 & 1244 & 1244 \\
\hline
\end{tabular}

Table 4: Robustness checks for all high-tech industries

\begin{tabular}{|c|c|c|c|c|c|c|c|c|}
\hline \multirow[b]{2}{*}{ Broadband index } & \multicolumn{2}{|c|}{ Robust (1) } & \multicolumn{2}{|c|}{ Robust (2) } & \multicolumn{2}{|c|}{ Robust (3) } & \multicolumn{2}{|c|}{ Tobit } \\
\hline & $\begin{array}{r}0.009 \\
(0.003)\end{array}$ & $\star \star *$ & $\begin{array}{r}0.006 \\
(0.002)\end{array}$ & ** & $\begin{array}{r}0.007 \\
(0.003)\end{array}$ & $\star \star \star$ & $\begin{array}{r}0.014 \\
(0.003)\end{array}$ & $\star \star \star *$ \\
\hline Distance MINT & $\begin{array}{l}-0.008 \\
(0.003)\end{array}$ & $\star \star \star *$ & $\begin{array}{l}-0.005 \\
(0.002)\end{array}$ & ** & $\begin{array}{r}-0.004 \\
(0.002)\end{array}$ & * & $\begin{array}{r}-0.013 \\
(0.003)\end{array}$ & $\star \star \star$ \\
\hline $\begin{array}{l}\text { Log(moterway inter- } \\
\text { changes) }\end{array}$ & $\begin{array}{l}-0.000 \\
(0.001)\end{array}$ & & $\begin{array}{l}-0.001 \\
(0.001)\end{array}$ & & $\begin{array}{l}-0.000 \\
(0.001)\end{array}$ & & $\begin{array}{r}0.001 \\
(0.001)\end{array}$ & \\
\hline $\begin{array}{l}\text { Long-distance train } \\
\text { stations }\end{array}$ & $\begin{array}{r}0.003 \\
(0.001)\end{array}$ & $\star \star \star$ & $\begin{array}{r}0.001 \\
(0.001)\end{array}$ & ** & $\begin{array}{r}0.002 \\
(0.001)\end{array}$ & ** & $\begin{array}{r}0.003 \\
(0.001)\end{array}$ & $\star \star \star$ \\
\hline $\begin{array}{l}\text { Agglomeration } \\
(>300,000 \text { inhabi- } \\
\text { tants) }\end{array}$ & $\begin{array}{r}0.006 \\
(0.001)\end{array}$ & $\star \star \star$ & $\begin{array}{r}0.004 \\
(0.001)\end{array}$ & $\star \star \star$ & $\begin{array}{r}0.003 \\
(0.001)\end{array}$ & ** & & \\
\hline $\begin{array}{l}\text { Share of inhabi- } \\
\text { tants reaching next } \\
\text { regional metropolis } \\
\text { within } 30 \text { min. }\end{array}$ & $\begin{array}{r}0.004 \\
(0.002)\end{array}$ & $\star \star \star *$ & $\begin{array}{r}0.003 \\
(0.002)\end{array}$ & ** & $\begin{array}{r}0.003 \\
(0.002)\end{array}$ & & & \\
\hline $\begin{array}{l}\text { Share of inhabi- } \\
\text { tants in municipali- } \\
\text { ties with } \\
<150 \text { inhabitants }\end{array}$ & $\begin{array}{l}-0.004 \\
(0.002)\end{array}$ & & $\begin{array}{r}0.001 \\
(0.002)\end{array}$ & & $\begin{array}{r}-0.001 \\
(0.002)\end{array}$ & & & \\
\hline $\begin{array}{l}\text { Share of employees } \\
\text { in manufacturing }\end{array}$ & & & $\begin{array}{r}0.002 \\
(0.007)\end{array}$ & & $\begin{array}{l}-0.004 \\
(0.007)\end{array}$ & & & \\
\hline $\begin{array}{l}\text { Share of employees } \\
\text { in business related } \\
\text { services }\end{array}$ & & & $\begin{array}{r}0.095 \\
(0.019)\end{array}$ & $\star \star \star$ & $\begin{array}{r}0.084 \\
(0.018)\end{array}$ & $\star \star \star$ & & \\
\hline Ich-AG & & & & & $\begin{array}{r}0.000 \\
(0.000)\end{array}$ & $\star \star \star$ & & \\
\hline $\begin{array}{l}\text { Share of employees } \\
\text { in firms > } 249 \text { em- } \\
\text { ployees }\end{array}$ & $\begin{array}{l}-0.020 \\
(0.006)\end{array}$ & $\star \star \star *$ & $\begin{array}{l}-0.024 \\
(0.006)\end{array}$ & $\star \star \star *$ & $\begin{array}{l}-0.020 \\
(0.006)\end{array}$ & $\star \star \star *$ & $\begin{array}{l}-0.010 \\
(0.006)\end{array}$ & \\
\hline $\begin{array}{l}\Delta \text { growth rate of } \\
\text { gross value added } \\
\text { in secondary sector }\end{array}$ & $\begin{array}{l}-0.004 \\
(0.006)\end{array}$ & & $\begin{array}{l}-0.003 \\
(0.006)\end{array}$ & & $\begin{array}{l}-0.004 \\
(0.006)\end{array}$ & & $\begin{array}{l}-0.002 \\
(0.006)\end{array}$ & \\
\hline $\begin{array}{l}\Delta \text { growth rate of } \\
\text { gross value added } \\
\text { in tertiary sector }\end{array}$ & $\begin{array}{l}-0.009 \\
(0.016)\end{array}$ & & $\begin{array}{l}-0.008 \\
(0.015)\end{array}$ & & $\begin{array}{l}-0.003 \\
(0.015)\end{array}$ & & $\begin{array}{l}-0.010 \\
(0.016)\end{array}$ & \\
\hline $\begin{array}{l}\text { Share of short-time } \\
\text { unemployed per } \\
\text { employees }\end{array}$ & $\begin{array}{l}-0.233 \\
(0.031)\end{array}$ & $\star \star \star *$ & $\begin{array}{l}-0.202 \\
(0.031)\end{array}$ & $\star \star \star$ & $\begin{array}{l}-0.171 \\
(0.031)\end{array}$ & $\star \star \star$ & $\begin{array}{l}-0.218 \\
(0.032)\end{array}$ & $\star \star \star *$ \\
\hline Eastern Germany & $\begin{array}{r}0.007 \\
(0.005)\end{array}$ & & $\begin{array}{r}0.005 \\
(0.005)\end{array}$ & & $\begin{array}{r}0.005 \\
(0.005)\end{array}$ & & $\begin{array}{r}0.008 \\
(0.006)\end{array}$ & \\
\hline $\begin{array}{l}\text { East * Unemploy- } \\
\text { ment }\end{array}$ & $\begin{array}{r}0.078 \\
(0.043)\end{array}$ & * & $\begin{array}{r}0.068 \\
(0.041)\end{array}$ & * & $\begin{array}{r}0.041 \\
(0.041)\end{array}$ & & $\begin{array}{r}-0.118 \\
(0.104)\end{array}$ & \\
\hline Constant & $\begin{array}{r}0.040 \\
(0.005)\end{array}$ & $\star \star \star$ & $\begin{array}{r}0.030 \\
(0.006)\end{array}$ & $\star \star \star *$ & $\begin{array}{r}0.003 \\
(0.008)\end{array}$ & & $\begin{array}{r}0.033 \\
(0.005)\end{array}$ & $\star \star \star$ \\
\hline
\end{tabular}




\begin{tabular}{|c|c|c|c|c|c|}
\hline \multirow{2}{*}{ Year dummies } & \multicolumn{5}{|c|}{ included } \\
\hline & & & & 0.011 & $\star \star \star \star$ \\
\hline Sigma & & & & $(0.000)$ & \\
\hline No. of obs. & 1250 & 1250 & 1250 & 1250 & \\
\hline
\end{tabular}

Table 5: Robustness checks for R\&D-intensive manufacturing

\begin{tabular}{|c|c|c|c|c|c|c|c|c|}
\hline & \multicolumn{2}{|c|}{ Robust (1) } & \multicolumn{2}{|c|}{ Robust (2) } & \multicolumn{2}{|c|}{ Robust (3) } & \multicolumn{2}{|c|}{ Tobit } \\
\hline Broadband index & $\begin{array}{r}0.001 \\
(0.001)\end{array}$ & * & $\begin{array}{r}0.001 \\
(0.001)\end{array}$ & * & $\begin{array}{r}0.001 \\
(0.001)\end{array}$ & * & $\begin{array}{r}0.002 \\
(0.001)\end{array}$ & $\star \star$ \\
\hline Distance MINT & $\begin{array}{r}-0.000 \\
(0.001)\end{array}$ & & $\begin{array}{r}-0.000 \\
(0.001)\end{array}$ & & $\begin{array}{r}0.000 \\
(0.001)\end{array}$ & & $\begin{array}{r}-0.001 \\
(0.001)\end{array}$ & \\
\hline $\begin{array}{l}\text { Log(moterway inter- } \\
\text { changes) }\end{array}$ & $\begin{array}{r}0.000 \\
(0.000)\end{array}$ & & $\begin{array}{l}-0.000 \\
(0.000)\end{array}$ & & $\begin{array}{l}-0.000 \\
(0.000)\end{array}$ & & $\begin{array}{r}0.000 \\
(0.000)\end{array}$ & \\
\hline $\begin{array}{l}\text { Long-distance train } \\
\text { stations }\end{array}$ & $\begin{array}{r}-0.000 \\
(0.000)\end{array}$ & & $\begin{array}{r}0.000 \\
(0.000)\end{array}$ & & $\begin{array}{r}0.000 \\
(0.000)\end{array}$ & & $\begin{array}{l}-0.000 \\
(0.000)\end{array}$ & \\
\hline $\begin{array}{l}\text { Agglomeration } \\
\text { (> 300,000 inhabi- } \\
\text { tants) }\end{array}$ & $\begin{array}{r}0.001 \\
(0.000)\end{array}$ & $\star \star *$ & $\begin{array}{r}0.000 \\
(0.000)\end{array}$ & * & $\begin{array}{r}0.000 \\
(0.000)\end{array}$ & & & \\
\hline $\begin{array}{l}\text { Share of inhabi- } \\
\text { tants reaching next } \\
\text { regional metropolis } \\
\text { within } 30 \text { min. }\end{array}$ & $\begin{array}{r}0.000 \\
(0.000)\end{array}$ & & $\begin{array}{r}0.000 \\
(0.000)\end{array}$ & & $\begin{array}{r}0.000 \\
(0.000)\end{array}$ & & & \\
\hline $\begin{array}{l}\text { Share of inhabi- } \\
\text { tants in municipali- } \\
\text { ties with } \\
<150 \text { inhabitants }\end{array}$ & $\begin{array}{r}-0.000 \\
(0.001)\end{array}$ & & $\begin{array}{r}0.000 \\
(0.000)\end{array}$ & & $\begin{array}{l}-0.000 \\
(0.001)\end{array}$ & & & \\
\hline $\begin{array}{l}\text { Share of employees } \\
\text { in manufacturing }\end{array}$ & & & $\begin{array}{r}0.006 \\
(0.002)\end{array}$ & $\star \star \star *$ & $\begin{array}{r}0.005 \\
(0.002)\end{array}$ & $\star \star \star$ & & \\
\hline $\begin{array}{l}\text { Share of employees } \\
\text { in business related } \\
\text { services }\end{array}$ & & & $\begin{array}{r}0.012 \\
(0.004)\end{array}$ & $\star \star \star$ & $\begin{array}{r}0.011 \\
(0.004)\end{array}$ & $\star \star \star *$ & & \\
\hline Ich-AG & & & & & $\begin{array}{r}0.000 \\
(0.000)\end{array}$ & * & & \\
\hline $\begin{array}{l}\text { Share of employees } \\
\text { in firms > } 249 \text { em- } \\
\text { ployees }\end{array}$ & $\begin{array}{r}-0.004 \\
(0.001)\end{array}$ & $\star \star \star$ & $\begin{array}{l}-0.006 \\
(0.001)\end{array}$ & $\star \star \star$ & $\begin{array}{l}-0.006 \\
(0.001)\end{array}$ & $\star \star \star$ & $\begin{array}{l}-0.003 \\
(0.001)\end{array}$ & $\star \star \star$ \\
\hline $\begin{array}{l}\Delta \text { growth rate of } \\
\text { gross value added } \\
\text { in secondary sector }\end{array}$ & $\begin{array}{r}-0.000 \\
(0.002)\end{array}$ & & $\begin{array}{l}-0.000 \\
(0.002)\end{array}$ & & $\begin{array}{l}-0.000 \\
(0.002)\end{array}$ & & $\begin{array}{l}-0.000 \\
(0.002)\end{array}$ & \\
\hline $\begin{array}{l}\Delta \text { growth rate of } \\
\text { gross value added } \\
\text { in tertiary sector }\end{array}$ & $\begin{array}{r}0.002 \\
(0.005)\end{array}$ & & $\begin{array}{r}0.001 \\
(0.005)\end{array}$ & & $\begin{array}{r}0.002 \\
(0.005)\end{array}$ & & $\begin{array}{r}0.002 \\
(0.005)\end{array}$ & \\
\hline $\begin{array}{l}\text { Share of short-time } \\
\text { unemployed per } \\
\text { employees }\end{array}$ & $\begin{array}{r}-0.029 \\
(0.007)\end{array}$ & $\star * \star$ & $\begin{array}{r}-0.021 \\
(0.007)\end{array}$ & $\star \star \star$ & $\begin{array}{r}-0.018 \\
(0.007)\end{array}$ & $\star \star \star *$ & $\begin{array}{r}-0.030 \\
(0.007)\end{array}$ & $\star \star *$ \\
\hline Eastern Germany & $\begin{array}{r}-0.000 \\
(0.001)\end{array}$ & & $\begin{array}{r}0.000 \\
(0.001)\end{array}$ & & $\begin{array}{r}0.000 \\
(0.001)\end{array}$ & & $\begin{array}{r}-0.000 \\
(0.001)\end{array}$ & \\
\hline $\begin{array}{l}\text { East * Unemploy- } \\
\text { ment }\end{array}$ & $\begin{array}{r}0.017 \\
(0.009)\end{array}$ & * & $\begin{array}{r}0.011 \\
(0.009)\end{array}$ & & $\begin{array}{r}0.009 \\
(0.009)\end{array}$ & & $\begin{array}{r}0.016 \\
(0.010)\end{array}$ & \\
\hline
\end{tabular}




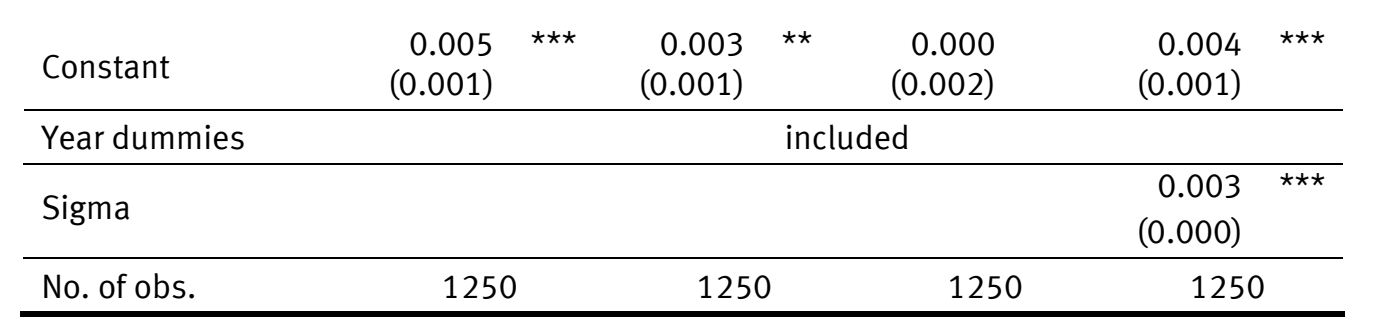

Table 6: Robustness checks for technology-intensive services

\begin{tabular}{|c|c|c|c|c|c|c|c|c|}
\hline \multirow[b]{2}{*}{ Broadband index } & \multicolumn{2}{|c|}{ Robust (1) } & \multicolumn{2}{|c|}{ Robust (2) } & \multicolumn{2}{|c|}{ Robust (3) } & \multicolumn{2}{|c|}{ Tobit } \\
\hline & $\begin{array}{r}0.007 \\
(0.002)\end{array}$ & $\star \star \star$ & $\begin{array}{r}0.004 \\
(0.002)\end{array}$ & * & $\begin{array}{r}0.005 \\
(0.002)\end{array}$ & ** & $\begin{array}{r}0.011 \\
(0.003)\end{array}$ & $\star \star \star$ \\
\hline Distance MINT & $\begin{array}{l}-0.007 \\
(0.002)\end{array}$ & $\star \star \star$ & $\begin{array}{l}-0.005 \\
(0.002)\end{array}$ & $\star \star$ & $\begin{array}{l}-0.004 \\
(0.002)\end{array}$ & * & $\begin{array}{l}-0.012 \\
(0.003)\end{array}$ & $\star \star \star$ \\
\hline $\begin{array}{l}\text { Log(moterway inter- } \\
\text { changes) }\end{array}$ & $\begin{array}{l}-0.000 \\
(0.001)\end{array}$ & & $\begin{array}{l}-0.001 \\
(0.001)\end{array}$ & & $\begin{array}{l}-0.000 \\
(0.001)\end{array}$ & & $\begin{array}{r}0.001 \\
(0.001)\end{array}$ & \\
\hline $\begin{array}{l}\text { Long-distance train } \\
\text { stations }\end{array}$ & $\begin{array}{r}0.003 \\
(0.001)\end{array}$ & $\star \star \star *$ & $\begin{array}{r}0.001 \\
(0.001)\end{array}$ & ** & $\begin{array}{r}0.002 \\
(0.001)\end{array}$ & ** & $\begin{array}{r}0.003 \\
(0.001)\end{array}$ & $\star \star \star$ \\
\hline $\begin{array}{l}\text { Agglomeration (> } \\
300,000 \text { inhabi- } \\
\text { tants) }\end{array}$ & $\begin{array}{r}0.005 \\
(0.001)\end{array}$ & $\star \star \star$ & $\begin{array}{r}0.003 \\
(0.001)\end{array}$ & $\star \star$ & $\begin{array}{r}0.003 \\
(0.001)\end{array}$ & $\star \star$ & & \\
\hline $\begin{array}{l}\text { Share of inhabitants } \\
\text { reaching next re- } \\
\text { gional metropolis } \\
\text { within } 30 \text { min. }\end{array}$ & $\begin{array}{r}0.004 \\
(0.002)\end{array}$ & ** & $\begin{array}{r}0.003 \\
(0.002)\end{array}$ & * & $\begin{array}{r}0.002 \\
(0.002)\end{array}$ & & & \\
\hline $\begin{array}{l}\text { Share of inhabitants } \\
\text { in municipalities } \\
\text { with } \\
<150 \text { inhabitants }\end{array}$ & $\begin{array}{l}-0.003 \\
(0.002)\end{array}$ & & $\begin{array}{r}0.001 \\
(0.002)\end{array}$ & & $\begin{array}{l}-0.001 \\
(0.002)\end{array}$ & & & \\
\hline $\begin{array}{l}\text { Share of employees } \\
\text { in manufacturing }\end{array}$ & & & $\begin{array}{l}-0.003 \\
(0.007)\end{array}$ & & $\begin{array}{l}-0.009 \\
(0.007)\end{array}$ & & & \\
\hline $\begin{array}{l}\text { Share of employees } \\
\text { in business related } \\
\text { services }\end{array}$ & & & $\begin{array}{r}0.085 \\
(0.017)\end{array}$ & $\star \star \star \star$ & $\begin{array}{r}0.076 \\
(0.017)\end{array}$ & $\star \star \star$ & & \\
\hline Ich-AG & & & & & $\begin{array}{r}0.000 \\
(0.000)\end{array}$ & $\star \star *$ & & \\
\hline $\begin{array}{l}\text { Share of employees } \\
\text { in firms > } 249 \text { em- } \\
\text { ployees }\end{array}$ & $\begin{array}{l}-0.017 \\
(0.005)\end{array}$ & $\star \star \star$ & $\begin{array}{l}-0.019 \\
(0.006)\end{array}$ & $\star \star \star$ & $\begin{array}{l}-0.015 \\
(0.006)\end{array}$ & $\star \star \star$ & $\begin{array}{l}-0.008 \\
(0.006)\end{array}$ & \\
\hline $\begin{array}{l}\Delta \text { growth rate of } \\
\text { gross value added } \\
\text { in secondary sector }\end{array}$ & $\begin{array}{l}-0.003 \\
(0.005)\end{array}$ & & $\begin{array}{l}-0.002 \\
(0.005)\end{array}$ & & $\begin{array}{l}-0.003 \\
(0.005)\end{array}$ & & $\begin{array}{r}-0.001 \\
(0.005)\end{array}$ & \\
\hline $\begin{array}{l}\Delta \text { growth rate of } \\
\text { gross value added } \\
\text { in tertiary sector }\end{array}$ & $\begin{array}{r}-0.018 \\
(0.015)\end{array}$ & & $\begin{array}{r}-0.016 \\
(0.014)\end{array}$ & & $\begin{array}{r}-0.011 \\
(0.014)\end{array}$ & & $\begin{array}{r}-0.019 \\
(0.015)\end{array}$ & \\
\hline $\begin{array}{l}\text { Share of short-time } \\
\text { unemployed per } \\
\text { employees }\end{array}$ & $\begin{array}{r}-0.206 \\
(0.030)\end{array}$ & $\star \star \star$ & $\begin{array}{r}-0.181 \\
(0.029)\end{array}$ & $\star \star \star ~$ & $\begin{array}{r}-0.154 \\
(0.029)\end{array}$ & $\star \star \star *$ & $\begin{array}{r}-0.192 \\
(0.031)\end{array}$ & $\star \star \star$ \\
\hline Eastern Germany & $\begin{array}{r}0.006 \\
(0.005)\end{array}$ & & $\begin{array}{r}0.004 \\
(0.005)\end{array}$ & & $\begin{array}{r}0.003 \\
(0.005)\end{array}$ & & $\begin{array}{r}0.007 \\
(0.006)\end{array}$ & \\
\hline
\end{tabular}




\begin{tabular}{|c|c|c|c|c|c|c|c|}
\hline $\begin{array}{l}\text { East * Unemploy- } \\
\text { ment }\end{array}$ & $\begin{array}{r}0.069 \\
(0.041)\end{array}$ & * & $\begin{array}{r}0.064 \\
(0.038)\end{array}$ & * & $\begin{array}{r}0.039 \\
(0.038)\end{array}$ & $\begin{array}{r}0.049 \\
(0.044)\end{array}$ & \\
\hline Constant & $\begin{array}{r}0.035 \\
(0.004) \\
\end{array}$ & $\star \star *$ & $\begin{array}{r}0.027 \\
(0.005) \\
\end{array}$ & $\star \star \star *$ & $\begin{array}{r}0.002 \\
(0.007) \\
\end{array}$ & $\begin{array}{r}0.028 \\
(0.004)\end{array}$ & $\star \star \star$ \\
\hline Year dummies & \multicolumn{7}{|c|}{ included } \\
\hline Sigma & & & & & & $\begin{array}{r}0.010 \\
(0.000) \\
\end{array}$ & 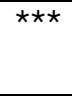 \\
\hline No. of obs. & 124 & & 1249 & & 1249 & 1249 & \\
\hline
\end{tabular}

Table 7: Robustness checks for software sector

\begin{tabular}{|c|c|c|c|c|c|c|c|c|}
\hline \multirow[b]{2}{*}{ Broadband index } & \multicolumn{2}{|c|}{ Robust (1) } & \multicolumn{2}{|c|}{ Robust (2) } & \multicolumn{2}{|c|}{ Robust (3) } & \multicolumn{2}{|c|}{ Tobit } \\
\hline & $\begin{array}{r}0.003 \\
(0.001)\end{array}$ & $\star \star \star$ & $\begin{array}{r}0.002 \\
(0.001)\end{array}$ & $\star \star \star$ & $\begin{array}{r}0.003 \\
(0.001)\end{array}$ & $\star \star \star$ & $\begin{array}{r}0.004 \\
(0.001)\end{array}$ & $\star \star \star$ \\
\hline Distance MINT & $\begin{array}{l}-0.002 \\
(0.001)\end{array}$ & ** & $\begin{array}{l}-0.001 \\
(0.001)\end{array}$ & & $\begin{array}{l}-0.001 \\
(0.001)\end{array}$ & & $\begin{array}{l}-0.004 \\
(0.001)\end{array}$ & $\star \star \star$ \\
\hline $\begin{array}{l}\text { Log(moterway inter- } \\
\text { changes) }\end{array}$ & $\begin{array}{r}0.000 \\
(0.000)\end{array}$ & & $\begin{array}{r}0.000 \\
(0.000)\end{array}$ & & $\begin{array}{r}0.000 \\
(0.000)\end{array}$ & & $\begin{array}{r}0.000 \\
(0.000)\end{array}$ & * \\
\hline $\begin{array}{l}\text { Long-distance train } \\
\text { stations }\end{array}$ & $\begin{array}{r}0.001 \\
(0.000)\end{array}$ & $\star \star \star$ & $\begin{array}{r}0.000 \\
(0.000)\end{array}$ & & $\begin{array}{r}0.000 \\
(0.000)\end{array}$ & & $\begin{array}{r}0.001 \\
(0.000)\end{array}$ & $\star \star \star$ \\
\hline $\begin{array}{l}\text { Agglomeration } \\
(>300,000 \text { inhabi- } \\
\text { tants) }\end{array}$ & $\begin{array}{r}0.001 \\
(0.001)\end{array}$ & & $\begin{array}{r}0.000 \\
(0.001)\end{array}$ & & $\begin{array}{l}-0.000 \\
(0.001)\end{array}$ & & & \\
\hline $\begin{array}{l}\text { Share of inhabitants } \\
\text { reaching next re- } \\
\text { gional metropolis } \\
\text { within } 30 \text { min. }\end{array}$ & $\begin{array}{r}0.002 \\
(0.001)\end{array}$ & $\star \star \star$ & $\begin{array}{r}0.001 \\
(0.001)\end{array}$ & ** & $\begin{array}{r}0.001 \\
(0.001)\end{array}$ & ** & & \\
\hline $\begin{array}{l}\text { Share of inhabitants } \\
\text { in municipalities } \\
\text { with } \\
<150 \text { inhabitants }\end{array}$ & $\begin{array}{l}-0.001 \\
(0.001)\end{array}$ & * & $\begin{array}{l}-0.000 \\
(0.001)\end{array}$ & & $\begin{array}{l}-0.001 \\
(0.001)\end{array}$ & & & \\
\hline $\begin{array}{l}\text { Share of employees } \\
\text { in manufacturing }\end{array}$ & & & $\begin{array}{l}-0.003 \\
(0.003)\end{array}$ & & $\begin{array}{l}-0.005 \\
(0.003)\end{array}$ & * & & \\
\hline $\begin{array}{l}\text { Share of employees } \\
\text { in business related } \\
\text { services }\end{array}$ & & & $\begin{array}{r}0.026 \\
(0.007)\end{array}$ & $\star \star \star$ & $\begin{array}{r}0.023 \\
(0.007)\end{array}$ & $\star \star \star$ & & \\
\hline Ich-AG & & & & & $\begin{array}{r}0.000 \\
(0.000)\end{array}$ & $\star \star \star$ & & \\
\hline $\begin{array}{l}\text { Share of employees } \\
\text { in firms > } 249 \text { em- } \\
\text { ployees }\end{array}$ & $\begin{array}{l}-0.003 \\
(0.002)\end{array}$ & & $\begin{array}{l}-0.003 \\
(0.002)\end{array}$ & & $\begin{array}{l}-0.002 \\
(0.002)\end{array}$ & & $\begin{array}{r}0.000 \\
(0.002)\end{array}$ & \\
\hline $\begin{array}{l}\Delta \text { growth rate of } \\
\text { gross value added } \\
\text { in secondary sector }\end{array}$ & $\begin{array}{l}-0.002 \\
(0.003)\end{array}$ & & $\begin{array}{l}-0.002 \\
(0.003)\end{array}$ & & $\begin{array}{l}-0.002 \\
(0.003)\end{array}$ & & $\begin{array}{l}-0.002 \\
(0.003)\end{array}$ & \\
\hline $\begin{array}{l}\Delta \text { growth rate of } \\
\text { gross value added } \\
\text { in tertiary sector }\end{array}$ & $\begin{array}{l}-0.008 \\
(0.006)\end{array}$ & & $\begin{array}{l}-0.008 \\
(0.006)\end{array}$ & & $\begin{array}{l}-0.006 \\
(0.006)\end{array}$ & & $\begin{array}{r}-0.010 \\
(0.006)\end{array}$ & \\
\hline $\begin{array}{l}\text { Share of short-time } \\
\text { unemployed per } \\
\text { employees }\end{array}$ & $\begin{array}{r}-0.071 \\
(0.012)\end{array}$ & $\star \star \star$ & $\begin{array}{r}-0.065 \\
(0.011)\end{array}$ & 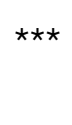 & $\begin{array}{c}-0.057 \\
(0.011)\end{array}$ & $\star \star \star$ & $\begin{array}{r}-0.070 \\
(0.013)\end{array}$ & $\star \star \star$ \\
\hline
\end{tabular}




\begin{tabular}{|c|c|c|c|c|c|c|c|c|}
\hline Eastern Germany & $\begin{array}{l}-0.002 \\
(0.002)\end{array}$ & & $\begin{array}{l}-0.003 \\
(0.002)\end{array}$ & * & $\begin{array}{l}-0.003 \\
(0.002)\end{array}$ & * & $\begin{array}{l}-0.001 \\
(0.002)\end{array}$ & \\
\hline $\begin{array}{l}\text { East * Unemploy- } \\
\text { ment }\end{array}$ & $\begin{array}{r}0.046 \\
(0.015)\end{array}$ & $\star \star \star ~$ & $\begin{array}{r}0.046 \\
(0.014)\end{array}$ & 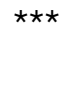 & $\begin{array}{r}0.039 \\
(0.014)\end{array}$ & $\star \star \star *$ & $\begin{array}{r}0.035 \\
(0.017)\end{array}$ & $\star \star$ \\
\hline Constant & $\begin{array}{r}0.007 \\
(0.002) \\
\end{array}$ & $\star \star \star ~$ & $\begin{array}{r}0.005 \\
(0.002) \\
\end{array}$ & $\star \star$ & $\begin{array}{r}-0.002 \\
(0.003) \\
\end{array}$ & & $\begin{array}{r}0.005 \\
(0.002) \\
\end{array}$ & $\star \star \star *$ \\
\hline Year dummies & \multicolumn{8}{|c|}{ included } \\
\hline Sigma & & & & & & & $\begin{array}{r}0.005 \\
(0.000)\end{array}$ & $\star \star \star \star ~$ \\
\hline No. of obs. & 1251 & & 1251 & & 1251 & & 1251 & \\
\hline
\end{tabular}

